\title{
ANALISIS KEMAMPUAN BERPIKIR TINGKAT TINGGI SISWA PADA MATERI RELASI DAN FUNGSI KELAS VIII DI SMPN 1 TANJUNGANOM
}

\author{
Ninda Sundari Anggraini ${ }^{1}$, Dewi Hamidah ${ }^{2 *}$, Dwi Shinta Rahayu ${ }^{3}$ \\ 1, 2,3Prodi Tadris Matematika Fakultas Tarbiyah, IAIN Kediri \\ Jalan Sunan Ampel 7, Kota Kediri, Indonesia \\ e-mail: ${ }^{2}$ dewi.hamidah@iainkediri.ac.id; \\ Submitted: November 24,2021 \\ Revised: January 6, 2022 \\ Accepted: January 19, 2022 \\ corresponding author*
}

\begin{abstract}
Abstrak
Penelitian ini bertujuan untuk mengetahui kemampuan berpikir tingkat tinggi siswa pada materi relasi dan fungsi. Jenis penelitian ini adalah penelitian kualitatif dengan subjek penelitian adalah siswa kelas VIII-1 SMPN 1 Tanjunganom Tahun Pelajaran 2020/2021 dengan jumlah siswa 32 orang. Data yang diperoleh dari tes kemampuan berpikir tingkat tinggi (HOTS) dan wawancara. Analisis data yang digunakan berupa analisis taksonomi Bloom. Dari hasil penelitian yang dilakukan oleh peneliti menunjukkan bahwa persentase taksonomi bloom berdasarkan masing-masing level C4 (menganalisis), C5 (mengevaluasi), dan C6 (mencipta) adalah $61,98 \%, 47,17 \%$, dan 48,96\%. Dari hasil penelitian diperoleh kemampuan HOTS pada siswa yaitu 1 siswa dengan kategori sangat baik, 6 siswa dalam kategori baik, 22 siswa dalam kategori cukup, 3 siswa dalam kategori kurang, dan tidak ada siswa dalam kategori sangat kurang.
\end{abstract}

Kata Kunci: kemampuan berpikir tingkat tinggi, relasi dan fungsi

\section{ANALYSIS OF STUDENTS' HIGHER ORDER THINKING SKILLS ON RELATION AND FUNCTION FOR CLASS VIII AT SMPN 1 TANJUNGANOM}

\begin{abstract}
This study aims to determine the students' higher order thinking skills (HOTS) in subject of relation and function. This type of research is a qualitative research with the research subjects being class VIII-1 of SMPN 1 Tanjunganom in the academic year 2020/2021 with a total of 32 students. The data obtained from the HOTS test and interviews. Analysis data used in the form of Bloom's taxonomy analysis. From the results of research conducted by researchers, it shows that the taxonomic percentages of blooms based on each level of C4 (analyze), C5 (evaluate), and C6 (create) are 61.98\%, 47.17\%, and 48.96\%. From the results of the study, the students' HOTS abilities were 1 student in the very good category, 6 students in the good category, 22 students in the sufficient category, 3 students in the poor category, and no students in the very poor category.
\end{abstract}

Keywords: higher order thinking skills, relation and function

\section{Pendahuluan}

Pelajaran matematika merupakan pembelajaran yang memiliki hubungan dengan banyak konsep (Novitasari, 2016). Matematika juga memiliki beberapa tujuan pembelajaran antara lain yaitu memecahkan masalah, memahami konsep matematik, penalaran, menyampaikan ide dengan menggunakan tabel, simbol, diagram atau media lain dengan tujuan memperjelas masalah (Wahyuddin \& Ihsan, 2016). Sebagai upaya mendukung tujuan pembelajaran matematika tercapai dengan baik maka pemerintah mengeluarkan pedoman Permendiknas Nomor 16 Tahun 2007 tentang Standar Kualifikasi Akademik dan Kompetensi Guru Mata Pelajaran. Dalam Permendiknas tersebut kompetensi guru yang harus dimiliki salah satunya adalah mengembangkan instrumen penilaian (Kemendikbud, 2007).

Penilaian merupakan pengukuran capaian hasil belajar siswa yang diperoleh dari suatu proses pengumpulan dan pengolahan informasi (Setiawati \& dkk, 2018). Dengan adanya instrumen yang berkualitas, penilaian hasil belajar siswa memiliki 
pengaruh langsung pada keakuratan status pencapaian hasil belajar yang didapatkan peserta didik (Budiman \& Jailani, 2014). Keberadaan instrumen penilaian hasil belajar menjadi hal yang penting dalam mengambil keputusan oleh guru dan pihak sekolah. Keputusan tersebut terkait pencapaian hasil belajar yang diantaranya adalah kemampuan berpikir tingkat tinggi.

Menurut Ennis (dalam Zakiyah dan Lestari, 2019) berpikir tingkat tinggi adalah proses berpikir secara reflektif yang terfokus pada apa yang dilakukan atau diyakini yang beberapa jenis diantaranya mencakup kemampuan berpikir kritis, logis, metakognitif, kreatif dan reflektif. Kemampuan berpikir tingkat tinggi biasa juga disebut dengan istilah higher-order thinking skill (HOTS) (Megawati dkk, 2020). Kemampuan ini bukanlah hal yang sederhana, melainkan suatu yang cukup kompleks. Kemampuan berpikir tingkat tinggi mencakup beberapa jenis diantaranya mencakup kemampuan berpikir kritis, kreatif, logis, metakognitif dan reflektif (Ahmadi, 2016). Oleh karena itu HOTS merupakan kemampuan yang perlu untuk dipelajari oleh siswa.

Untuk mengukur kemampuan berpikir tingkat tinggi pada siswa dapat menggunakan materi relasi dan fungsi pada jenjang sekolah SMP. Materi relasi dan fungsi merupakan materi yang memiliki integrasi dengan agama antara lain yaitu aqidah, akhlak, dan ibadah (Febryanti \& Ahmad, 2019). Terdapat banyak permasalahan pada kehidupan sehari-hari yang memiliki hubungan dengan materi tersebut. Beberapa diantaranya yaitu konversi waktu dari jam ke menit, kurs mata uang, harga belanja barang, pendonoran darah dan lainlain (Nurbaktiono \& dkk, 2019). Sejalan dengan penelitian yang dilakukan oleh Andini dan Warmi (2019) yang membahas tentang kemampuan berpikir kritis matematis yang masih tergolong rendah dalam kemampuan HOTS. yaitu pada ratarata persentase $41,54 \%$. Pada materi relasi dan fungsi masih banyak siswa yang belum mampu menyerap pemahaman dari penjelasan guru mengenai materi tersebut (Hanifah, 2019). Selain itu, pada penelitian Yanti dkk (2019) kemampuan komunikasi matematis dan pemahaman pada materi relasi dan fungsi ditemukan sebagian besar siswa mengalami kesulitan dalam menyelesaikan permasalahan yang disebabkan karena siswa masih kurang dalam menguasai pertanyaan serta kurang antusias dalam memahami pertanyaan. Selanjutnya hasil penelitian yang dilakukan oleh Septiana, Fatimah, \& Suswigi (2019) menyatakan bahwa dalam menyelesaikan permasalahan relasi dan fungsi, siswa masih melakukan beberapa kesalahan yang disebabkan karena pemahaman konsep yang kurang dimiliki siswa pada tahap menganalisis serta kesulitan pada tahap mengevaluasi karena siswa memiliki pemahaman yang kurang dalam memahami materi. Dengan demikian kemampuan berpikir tingkat tinggi perlu diteliti pada materi relasi dan fungsi.

Oleh karena itu pada penelitian ini bertujuan menggali HOTS peserta didik pada level $\mathrm{C} 4$ (menganalisis), C5 (mengevaluasi) dan C6 (menciptakan). Selain itu peneliti juga ingin mendeskripsikan kategori kemampuan berpikir tingkat tinggi yang diperoleh peserta didik di SMPN 1 Tanjunganom.

\section{Metode Penelitian}

Penelitian ini menggunakan jenis penelitian kualitatif yang bertujuan untuk meneliti kondisi suatu objek yang alamiah dan berlandaskan kepada filsafat postpositivisme (Sugiyono, 2015). Hasil penelitian ini mendeskripsikan bagaimana kemampuan berpikir tingkat tinggi siswa. Data dikumpulkan melalui tes yang melibatkan 32 siswa kelas VIII di SMPN 1 Tanjunganom dan wawancara yang didasarkan pada hasil analisis jawaban siswa kepada 5 subjek wawancara yang masing-masing mewakili kategori HOTS. Selanjutnya pada setiap level menganalisis, mengevaluasi dan menciptakan, nilai hasil jawaban siswa dikelompokkan dalam 5 kategori penilaian. Berikut rumus yang digunakan untuk menentukan nilai pada setiap level soal:

$$
\text { Nilai }=\frac{\text { Jumlah skor yang diperoleh }}{\text { Skor Maksimum }} \times 100
$$

(Suharsimi, 2013)

Tabel 1. Kategori pada HOTS

\begin{tabular}{cl}
\hline Nilai Siswa & Kategori Penilaian \\
\hline $80<x \leq 100$ & Sangat Baik \\
$60<x \leq 80$ & Baik \\
$40<x \leq 60$ & Cukup \\
$20<x \leq 40$ & Kurang \\
$\leq 20$ & Sangat Kurang \\
\hline
\end{tabular}

(Prasetyani \& dkk, 2016)

Untuk mengecek keabsahan data, dilakukan triangulasi teknik dengan membandingkan hasil tes dan wawancara serta pemeriksaan teman sejawat.

\section{Hasil dan Pembahasan}

Berdasarkan hasil tes kemampuan berpikir tingkat tinggi (HOTS) siswa kepada 32 siswa, peneliti melakukan rekap nilai. Berdasarkan hasil rekap nilai tersebut, diperoleh data persentase ratarata kemampuan berpikir tingkat tinggi subjek 
pada setiap level yaitu: menganalisis (C4) $61,98 \%$, mengevaluasi (C5) 47,17\%, dan menciptakan (C6) $48,98 \%$.

Setelah dilakukan rekap nilai dari seluruh subjek, subjek dikategorikan berdasarkan kriteria pada Tabel 1. Dari pengkategorian hasil tes berbasis HOTS didapatkan data: 1 siswa berada pada kategori sangat baik, 6 siswa pada kategori baik, 22 siswa pada kategori cukup, 3 siswa pada kategori kurang, dan tidak ada siswa yang berada pada kategori sangat kurang. Dari semua kategori yang terisi diambil 1 subjek wawancara untuk mewakili setiap kategori HOTS. Kategori sangat baik diwakili oleh S25, kategori baik diwakili oleh S22, kategori cukup diwakili oleh S12, dan kategori kurang diwakili oleh S2. Berikut pemaparan hasil penelitian dan pembahasan kemampuan berpikir tingkat tinggi (HOTS) siswa pada level C4, C5 dan C6 pada setiap kategori.

\subsection{Level Menganalisis (C4)}

\subsubsection{Siswa dengan Kategori Sangat Baik}

Berikut ini hasil tes siswa kategori sangat baik.

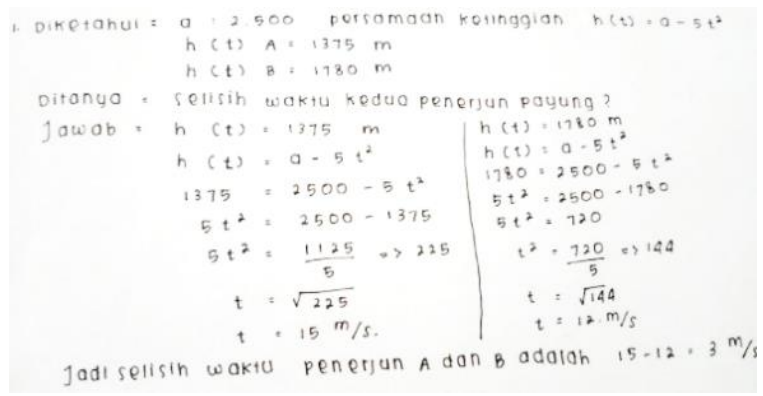

Gambar 1. Jawaban Siswa Kategori Sangat Baik

Hasil wawancara menunjukkan bahwa siswa pada kategori sangat baik menguraikan informasi yang ada pada soal dan mampu untuk menyajikannya dalam pemodelan matematika yang telah dipelajari. Siswa melakukan proses substitusi yang dilakukan dengan baik dan runut berdasarkan proses pengerjaannya. Siswa masih kurang lengkap dalam memberikan kejelasan jawaban. Namun demikian, siswa menyajikan kesimpulan dari hasil pekerjaannya.

Berdasarkan hasil tes dan wawancara, dapat diketahui bahwa pada level menganalisis siswa pada kategori sangat baik mampu menyajikan permasalahan dengan lengkap. Siswa mampu memahami permasalahan dengan baik dan memaparkan jawabannya. Hal ini Sejalan dengan penelitian yang dilakukan oleh Nurhayati dan Angraeni (2017) pada indikator menganalisis siswa mampu menguraikan informasi, konsep serta langkah penyelesaian yang tepat. Jika analisis yang dilakukan benar maka penyelesaian yang dituliskan akan mengarah kepada penyelesaian soal tersebut.

\subsubsection{Siswa dengan Kategori Baik}

Berikut ini hasil tes siswa kategori baik.

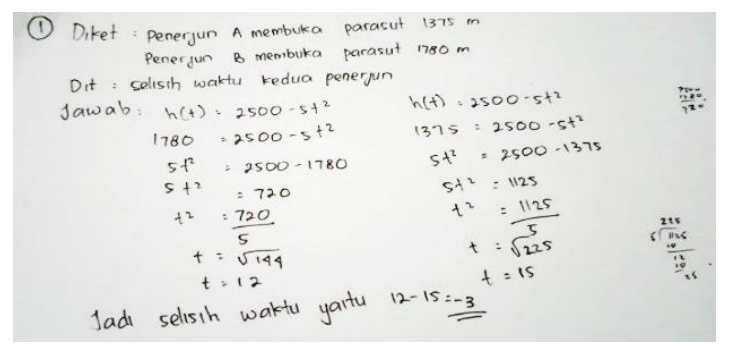

Gambar 2. Jawaban Siswa dengan Kategori Baik

Hasil wawancara menunjukkan bahwa siswa kategori baik mampu menguraikan permasalahan pada soal dalam bentuk diketahui dan ditanya. Siswa merasa bingung bagaimana cara untuk memodelkannya dalam bentuk matematika. Siswa melakukan proses pengurangan namun terdapat kesalahan dalam substitusi nilai $\mathrm{h}(\mathrm{t})$. Proses selisih yang dilakukan siswa terdapat kesalahan dalam meletakkan nilai hasil dari substitusi. Siswa menarik kesimpulan pada hasil pekerjaannya.

Berdasarkan hasil tes dan wawancara dapat diketahui bahwa siswa kategori baik pada level menganalisis dapat memahami permasalahan dengan baik namun kurang mampu dalam menyajikannya ke dalam model matematika. Langkah pekerjaan siswa dikerjakan dengan runtut dari tahap awal sampai tahap akhir menyimpulkan solusi permasalahan. Hal ini, sejalan dengan penelitian yang dilakukan oleh Parhusip (2019) siswa dengan kategori baik pada level menganalisis mampu untuk memahami informasi dan menyajikannya dalam bentuk diketahui dan ditanyakan. Namun dalam proses pengerjaannya siswa masih mengalami kekeliruan

\subsubsection{Siswa dengan Kategori Cukup}

Berikut ini hasil tes siswa kategori cukup

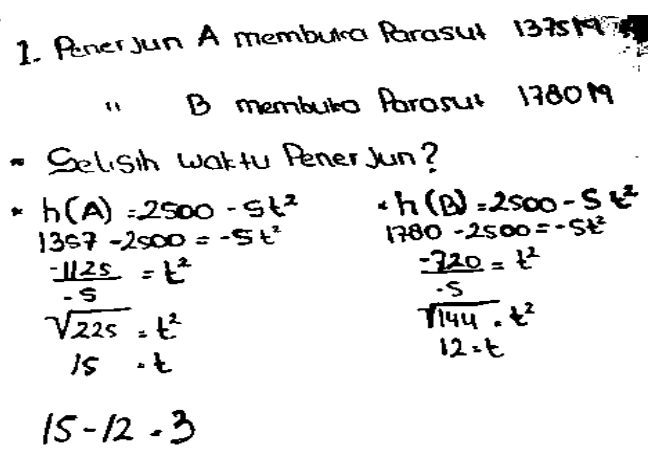

Gambar 3. Jawaban Siswa dengan Kategori Cukup

Hasil wawancara menunjukkan bahwa siswa mampu menganalisis apa yang diketahui dan 
ditanya pada permasalahan tersebut, namun siswa masih belum mampu menentukan model matematikanya. Siswa melakukan kesalahan dalam proses menentukan hasil akhir karena siswa hanya mengerjakan dengan cara uji coba saja.

Berdasarkan hasil tes dan wawancara dapat diketahui bahwa pada level menganalisis proses analisis soal yang dilakukan oleh siswa pada kategori cukup sudah baik namun belum mampu menyajikannya dengan menggunakan model matematika serta masih ditemukan kesalahan di akhir proses pengerjaan. Hal ini sejalan dengan penelitian Purbaningrum (2017) siswa dengan kategori cukup pada level menganalisis mampu untuk menguraikan dan memeriksa informasi yang ada ke dalam bagian yang sederhana dan mampu merumuskan pertanyaan.

\subsubsection{Siswa dengan Kategori Kurang}

Berikut ini hasil tes siswa kategori kurang

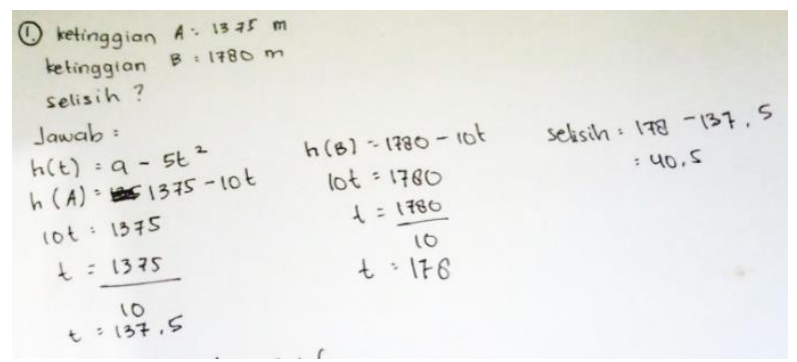

Gambar 4. Jawaban Siswa dengan Kategori Kurang

Hasil wawancara menunjukkan bahwa Siswa mampu dalam merumuskan permasalahan dalam bentuk diketahui dan ditanya. Siswa melakukan substitusi ke dalam soal tetapi terjadi kesalahan dalam meletakkan nilainya. Siswa melakukan kesalahan dalam perhitungan yaitu pada bentuk kuadrat. Hal tersebut terjadi karena siswa belum mampu untuk memahami cara penyelesaian dan belum menguasai materi relasi dan fungsi. Siswa mampu menarik kesimpulan tetapi terjadi kesalahan dalam perhitunagannya.

Berdasarkan hasil tes dan wawancara dapat diketahui bahwa pada level menganalisis siswa mampu untuk memahami informasi yang ada pada permasalahan namun siswa mengalami kesulitan dalam menentukan penyelesaiannya karena kurnag penguasaan konsep. Hal ini sejalan dengan penelitian yang dilakukan oleh Kurniati, dkk (2016) siswa pada level menganalisis kurang mampu dalam mengidentifikasi argumen, menganalisis ide utama untuk menjawab soal. Dengan demikian siswa memiliki kemampuan analisis yang kurang baik.

\subsection{Level Mengevaluasi (C5)}

\subsubsection{Siswa dengan Kategori Sangat Baik}

baik

Berikut ini hasil tes siswa kategori sangat

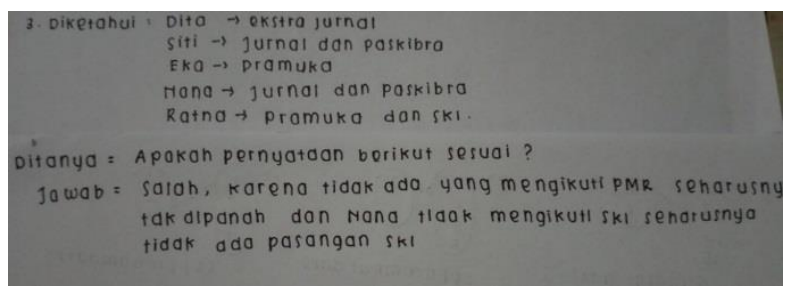

Gambar 5. Jawaban Siswa dengan Kategori Sangat Baik

Hasil wawancara menunjukkan bahwa Siswa menguraikan apa yang diketahui dari soal dengan jelas. Siswa juga mampu menjelaskan permasalahan yang harus dijawab pada soal. Siswa secara tegas menjawab permasalahan dengan menolak pernyataan yang disajikan dengan memberikan alasan yang kritis dan melakukan pengamatan yang teliti.

Berdasarkan hasil tes dan wawancara, pada level mengevaluasi siswa kategori sangat baik mampu memahami soal dengan baik. Siswa mampu merumuskan permasalahan dengan jelas dan menjelaskan alasan kritisnya sebagai landasan untuk menjawab pertanyaan. Hal ini sesuai dengan penelitian Prasetyani dkk (2016) pada level mengevaluasi siswa mampu untuk menentukan permasalahan dengan tepat, memahami pertanyaan dengan benar, dan mampu untuk memberikan alasan/bukti untuk menyelesaikan permasalahan tersebut.

\subsubsection{Siswa dengan Kategori Baik.}

Berikut ini hasil tes siswa kategori baik

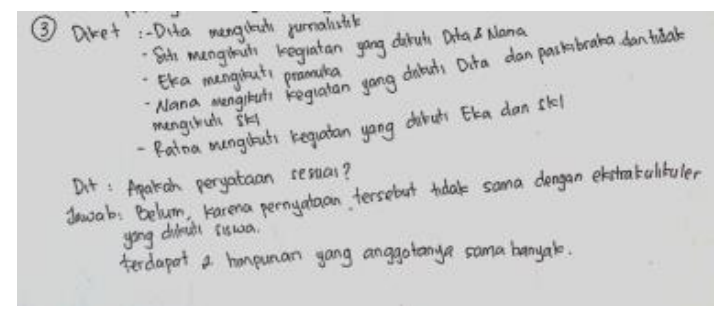

Gambar 6. Jawaban Siswa dengan Kategori Baik

Hasil wawancara menunjukka bahwa siswa mampu menguraikan apa yang diketahui dan ditanya pada soal meskipun kurang lengkap. Siswa menjawab dengan benar, tetapi alasan yang diberikan oleh siswa masih kurang tepat karena hanya sebatas hasil pengamatan yang terlihat.

Berdasarkan hasil tes dan wawancara, pada level mengevaluasi siswa kategori baik mampu memahami masalah dengan baik dan benar. Siswa sudah menunjukkan kemampuan berargumen 
untuk menjawab permasalahan hanya saja argumen pada proses penyelesaian masalah belum sepenuhnya kritis dan jelas. Hasil penelitian ini sesuai dengan penelitian yang dilakukan oleh Rahman dkk (2019) pada level mengevaluasi siswa mengalami kesalahan saat melakukan proses penyelesaian

\subsubsection{Siswa dengan Kategori Cukup}

Berikut ini hasil tes siswa kategori cukup

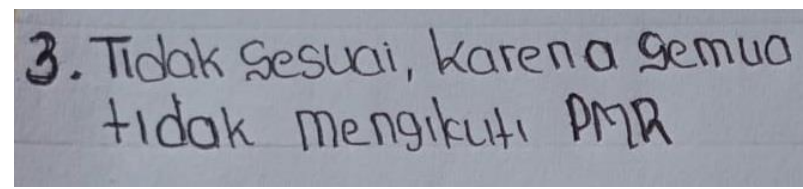

Gambar 7. Jawaban Siswa dengan Kategori Cukup

Hasil wawancara menunjukkan bahwa siswa mampu menjelaskan apa yang diketahui namun tidak menuliskannya dalam lembar jawaban. Siswa melakukan pengamatan pada diagram untuk menjawab permasalahan. Siswa berusaha memberikan argumen terkait jawabannya tapi secara singkat dan kurang lengkap. Siswa juga kurang mampu membuat kesimpulan akhir atas pengerjaannya karena merasa bingung dengan pertanyaannya. Hal ini dikarenakan siswa tidak terbiasa dengan soal semacam itu (tipe HOTS).

Berdasarkan hasil tes dan wawancara diperoleh data bahwa pada Level mengevaluasi meskipun Siswa kategori cukup sudah memberikan alasan, namun alasan yang diberikan oleh siswa kurang tepat sehingga siswa kesulitan membuat simpulan atas jawaban permasalahan yang dihadapi. Hal ini sejalan dengan penelitian Prasetyani dkk (2016) yang menemukan bahwa pada level mengevaluasi siswa kurang mampu untuk menuliskan, mendukung, dan menulis kesimpulan dengan tepat.

\subsubsection{Siswa dengan Kategori Kurang}

Berikut ini hasil tes siswa kategori kurang

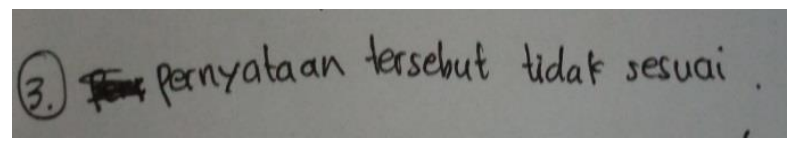

Gambar 8. Jawaban Siswa dengan Kategori Kurang

Hasil wawancara menunjukkan bahwa Siswa hanya mampu membaca apa yang diketahui dan ditanya dari soal, kurang memahami maksud permasalahan dalam soal. Siswa juga belum dapat menyajikan alasan sebagai landasan menjawab soal tersebut. Hal ini disebabkan selain karena siswa kurang mampu memahami informasi yang ada dalam permasalahan juga karena siswa kurang memahami materi.
Berdasarkan hasil tes dan wawancara, pada level mengevaluasi siswa kategori kurang masih kurang mampu memahami informasi dan permasalahan pada soal. Meskipun siswa memberikan jawaban dengan menolak pernyataan yang disajikan dalam soal, siswa belum mampu menyajikan alasan yang mendukung jawaban tersebut. Hal ini sesuai dengan penelitian Purbaningrum (2017) pada level mengevaluasi siswa kurang mampu dalam menilai, menyangkal, mengkritik dan melakukan sebuah pengujian untuk menerima atau menolak pertanyaan.

\subsection{Level Menciptakan (C6)}

\subsubsection{Siswa dengan Kategori Sangat Baik}

Berikut ini hasil tes siswa kategori sangat baik.
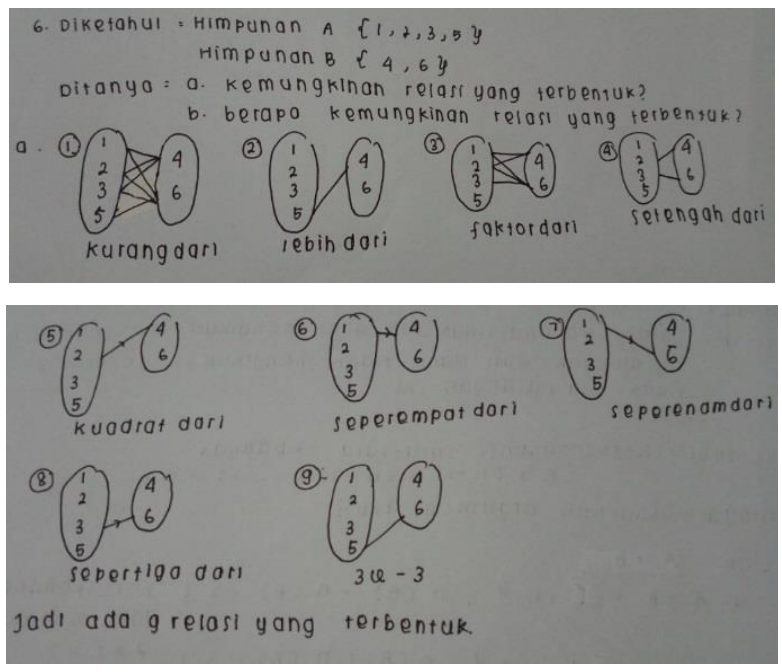

Gambar 9. Jawaban Siswa dengan Kategori Sangat Baik

Hasil wawancara menunjukkan bahwa Siswa mampu memaparkan apa yang diketahui dan ditanyakan dari soal. Siswa mampu membuat sebanyak sembilan relasi yang dinyatakan dengan menggunakan diagram panah meskipun ada diantaranya yang kurang tepat. Proses penyelesaian yang dilakukan siswa dilakukan dengan membentuk relasi yang umum sampai membentuk relasi sendiri dengan menggunakan fungsi aljabar. Siswa menyebutkan banyaknya jumlah relasi yang mungkin berdasarkan relasi yang terbentuk.

Berdasarkan hasil tes dan wawancara, diketahui bahwa pada level mencipta siswa kategori sangat baik mampu memahami masalah yang ada. Siswa juga menunjukkan kemampuan menentukan strategi untuk menyelesaikan masalah dengan membentuk relasi yang umum sampai relasi dengan fungsi aljabar. Pada peneliti Nurhayati dan Angraeni (2017) yang menunjukkan siswa pada kategori sangat baik mampu untuk 
menentukan ide awal untuk menyelesaikan permasalahan, mampu menganalisis permasalahan, mampu membentuk sesuatu yang baru dan mampu untuk membuat produk. Dalam penelitian ini, siswa sangat baik dapat menyajikan lebih banyak relasi daripada siswa-siswa yang lain dan membentuk relasi yang tidak atau jarang dibentuk oleh siswa lain, misalnya relasi dengan fungsi aljabar dan relasi yang berkaitan dengan pecahan.

\subsubsection{Siswa dengan Kategori Baik}

Berikut ini hasil tes siswa kategori baik

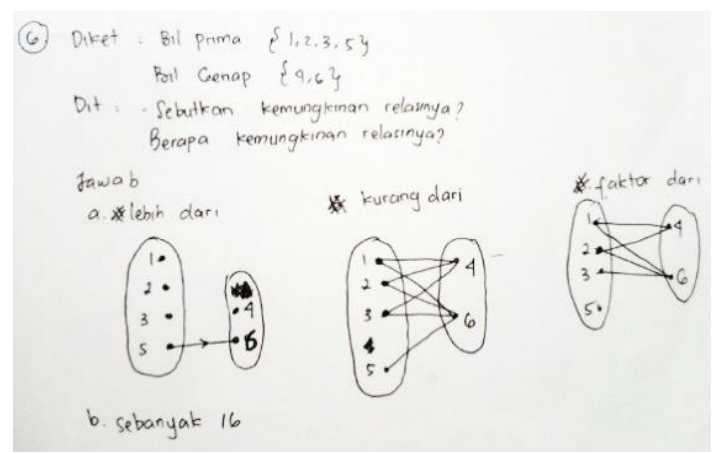

Gambar 10. Jawaban Siswa dengan Kategori Baik

Hasil wawancara menunjukkan Siswa mampu menyebutkan apa yang diketahui dan yang ditanyakan dengan lengkap. Siswa juga menyajikan anggota himpunan menggunakan diagram panah dengan benar. Siswa mampu membentuk tiga relasi dengan menggunakan diagram panah meskipun tidak semuanya benar. Siswa merasa kebingungan dalam menentukan langkah awal untuk menjawab permasalahan. Hal itu terjadi karena siswa kurang memahami materi relasi dan fungsi. Siswa menentukan banyaknya kemungkinan relasi dengan menggunakan rumus pemetaan tanpa disertai alasan dan belum dapat menunjukkan bentuk-bentuk relasi sebanyak itu.

Berdasarkan hasil tes dan wawancara, pada level menciptakan siswa kategori baik belum mampu menyelesaikan permasalahan dengan sepenuhnya benar. Jawaban siswa menggunakan rumus pemetaan kurang sesuai permasalahan yang dihadapi dan juga tidak disertai dengan alasan maupun bentuk relasi yang dimaksud. Hal ini sejalan dengan penelitian yang dilakukan oleh Dinni (2018) siswa pada level menciptakan belum mampu dalam menyelesaikan permasalahan yang sesuai dengan permasalahan tersebut.

\subsubsection{Siswa dengan Kategori Cukup}

Berikut ini hasil tes siswa kategori cukup.

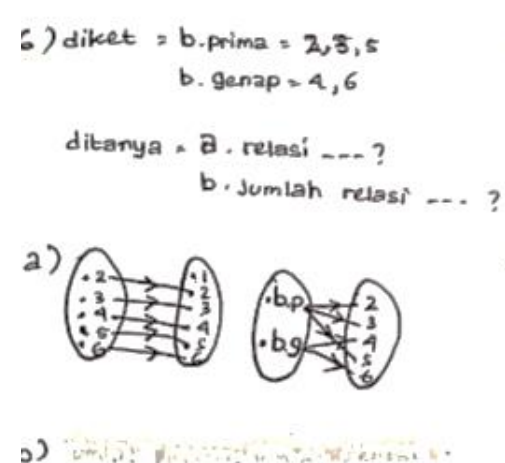

Gambar 11. Jawaban Siswa dengan Kategori Cukup

Siswa menjelaskan apa yang diketahui dan ditanyakan pada permasalahan tersebut dengan lengkap. Siswa juga mampu menyebutkan anggota dari kedua himpunan dengan benar. Siswa hanya mampu menyajikan relasi dengan dua diagram panah dan kesulitan menyebutkan "nama" relasi yang terbentuk pada diagram tersebut. Siswa tidak mampu menentukan berapa banyaknya kemungkinan relasi yang dapat terbentuk karena belum mengetahui relasi lain selain yang telah dia bentuk.

Berdasarkan hasil tes dan wawancara dapat diketahui bahwa Pada level mencipta siswa kategori cukup dapat menjelaskan informasi dan permasalahan dalam soal meskipun dalam penulisannya masih belum menggunakan representasi yang tepat. Siswa juga belum mampu menyelesaikan permasalahan karena kurang mampu membentuk relasi-relasi yang sesuai dengan permasalahan. Hal ini sejalan dengan penelitian Dinni (2018) yang menunjukkan siswa dengan kategori cukup dengan level menciptakan merasa kesulitan dikarenakan belum mengetahui penyelesaian dari soal tersebut

\subsubsection{Siswa dengan Kategori Kurang}

Berikut ini hasil tes siswa kategori kurang

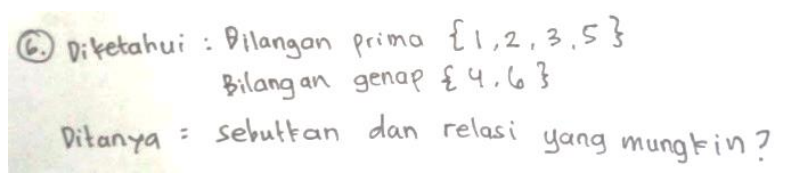

Gambar 11. Jawaban Siswa dengan Kategori Kurang

Hasil wawancara menunjukkan bahwa Siswa kurang mampu menyebutkan apa yang diketahui dan ditanyakan dengan lengkap. Siswa hanya membaca dan menyalin informasi dari soal. Siswa tidak melakukan proses penyelesaian dalam memecahkan permasalahan karena Siswa kesulitan memahami permasalahan yang ada. Hal ini disebabkan kurang familiarnya siswa dengan soal bertipe HOTS dan kurangnya minat belajar siswa ketika pembelajaran materi relasi dan fungsi 
Berdasarkan hasil tes dan wawancara, Siswa kategori kurang pada level menciptakan kurang mampu memaparkan informasi yang ada pada permasalahan. Siswa tidak melakukan proses penyelesaian masalah karena kurang memahami permasalahan dan belum pernah belajar tentang soal-soal yang berbasis HOTS. Selain itu, siswa juga kurang termotivasi belajar relasi dan fungsi. Hal ini sesuai dengan penelitian Purbaningrum (2017) pada tahap mengkreasi siswa kurang mampu untuk menggeneralisasikan ide terhadap sesuatu yang baru dan mengorganisasikan unsurunsur menjadi struktur yang baru.

\section{Kesimpulan}

Berdasarkan analisis data yang telah diperoleh dapat disimpulkan bahwa kemampuan berpikir tingkat tinggi siswa pada materi relasi dan fungsi kelas VIII di SMPN 1 Tanjunganom menunjukkan persentase taksonomi bloom dengan rata-rata $\mathrm{C} 4, \mathrm{C} 5$, dan $\mathrm{C} 6$ adalah $61,98 \%, 47,17 \%$ dan 48,96\%. Dari 32 siswa, 1 siswa diantaranya dalam kategori sangat baik, 6 siswa berkategori baik, 22 siswa berkategori cukup, 3 siswa berkategori kurang dan tidak ditemukan siswa yang berkategori sangat kurang. Secara umum dalam penelitian ini siswa memiliki kemampuan berpikir tingkat tinggi yang cukup.

\section{Daftar Pustaka}

Ahmadi, Y. (2016). Analisis Kemampuan Berpikir Kritis Matematis Siswa pada Materi Segitiga. Skripsi. Jakarta: UIN Syarif hidayatullah.

Andini, V., \& Warmi, A. (2019). Analisis Tingkat Kemampuan Berpikir Kritis Matematis Siswa SMP Kelas VIII Pada Materi Relasi dan Fungsi. Prosiding Sesiomadika. Universitas Singaperbangsa Karawang.

Budiman, A., \& Jailani. (2014). Pengembanagn Instrumen Asesmen Higher Order Thinking Skill (HOTS) Pada Mata Pelajaran Matematika SMP Kelas VIII Semester 1. Jurnal Riser Pendidikan Matematika, Vol. 1 No. 2.

Dinni, H. N. (2018). HOTS (High Order Thinking Skills) dan Kaitannya dengan Kemampuan Literasi Matematika. PRISMA.

Fatimah, S., Muhsetyo, G., \& Rahardjo, S. (2019). Proses Berpikir Tingkat Tinggi Siswa SMP Dalam Menyelesaikan Soal PISA dan Scaffoldingnya. JKPM, Vol. 3 No. 1.

Febryanti, \& Ahmad, H. (2019). Analisis Pemahaman Konsep Relasi dan Fungsi yang Terintegrasi Nilai-Nilai Islami. Prosiding. SI MaNIs.

Hanifah, R., Noornia, A., \& Sampoerno, P. D. (2019). Pengembangan Pembelajaran Dalam
Membangun Pemahaman Relasional Siswa Melalui Pendekatan PMRI Materi Relasi Fungsi. Prima: Jurnal Pendidikan Matematika, Vol. 3, No. 2.

Kemdikbud. (2007). Lampiran Peraturan Menteri Pendidikan Nasional. Nomor 16 Tahun 2007 tanggal 4 Mei 2007 Standar Kualifikasi Akademik dan Kompetensi Guru.

Kurniati, D., Harimukti, R., \& Jamil, N. A. (2016). Kemampuan Berikir Tingkat Tinggi Siswa SMP Di Kabupaten Jember Dalam Menyelesaikan Soal Berstandar PISA. Jurnal Penelitian dan Evaluasi Pendidikan, Vol. 20, No. 2.

Megawati, Wardani, A. K., \& Hartatiana. (2020). Kemampuan Berpikir Tingkat Tinggi Siswa SMP dalam Menyelesaikan Soal Matematika Model PISA. Jurnal Pendidikan Matematika, Vol. 14, No. 1.

Novitasari, D. (2016). Pengaruh Penggunaan Multimedia Interaktif Terhadap Kemampuan Pemahaman Konsep Matematis Siswa. FIBONACCI, Vol. 2, No. 2.

Nurhayati, \& Angraeni, L. (2017). Analisis Kemampuan Berpikir Tingkat Tinggi Mahasiswa (Higher Order Thinking) dalam Menyelesaikan Soal Konsep Optika melalui Model Problem Based Learning. JPPPF, Vol. 3, No. 2.

Prasetyani, E., Hartono, Y., \& Susanti, E. (2016). Kemampuan Berpikir Tingat Tinggi Siswa Kelas XI dalam Pembelajaran Trigonometri Berbasis Masalah di SMA Negeri 18 Palembang. Jurnal Gantang, Vol. 1, No. 1.

Parhusip, G. D. (2019). Analisis Kemampuan Berpikir Tingkat Tinggi Mahasiswa Program Studi Matematika Angkatan 2018 Kelas C Universitas Sanata Dharma untuk Materi Jarak pada Mata Kuliah Geometri Ruang. Skripsi. Yogyakarta: Universitas Sanata Dharma.

Purbaningrum, K. A. (2017). Kemampuan Berpikir Tingkat Tinggi Siswa SMP dalam Pemecahan Masalah Matematika Ditinjau Dari Gaya Belajar. JPPM, Vol. 10, No. 2.

Rahman, A., Asdar, \& Surahman, N. I. (2019). Analisis Keterampilan Berpikir Tingkat Tinggi Siswa dalam Pemecahan Masalah Matematika Berdasarkan Taksonomi Anderson. Issues in Mathematics Education, Vol. 3, No. 2.

Septiana, U., Fatimah, \& Suswigi. (2019). Analisis Kemampuan Penalaran Matematik Siswa MTs Pada Materi Relasi dan Fungsi. Journal On Education.

Setiawati, W., Asmira, O., \& dkk. (2018). Buku Penilaian Berorientasi Higher Order Thinking Skills. Jakarta: Direktorat Jenderal Guru dan Tenaga Kependidikan.

Suharsimi, A. (2013). Dasar-dasar Evaluasi Pendidikan. Jakarta: Bumi Aksara.

Wahyuddin, \& Ihsan, M. (2016). Analisis Kemampuan Menyelesaikan Soal Cerita Matematika Ditinjau dari Kemampuan Verbal pada Siswa Kelas VII SMP Muhammadiyah Se-Kota Makassar. Suska Journal of Mathematics Education, Vol. 2, No. 2. 
Yanti, R. N., Melati, A. S., \& Zanty, L. S. (2019). Analisis Kemampuan Pemahaman dan Kemampuan Komunikasi Matematis Siswa SMP pada Materi Relasi dan Fungsi. Jurnal Cendekia: Jurnal Pendidikan Matematika, Vol. 3 No. 1. 